\title{
The Economics of Debt Collection: Enforcement of Consumer Credit Contracts
}

\author{
Viktar Fedaseyeu ${ }^{\mathrm{a}}$ and Robert Hunt ${ }^{\mathrm{b}}$
}

March 1, 2014

\begin{abstract}
In the U.S., third-party debt collection agencies employ more than 140,000 people and recover more than $\$ 50$ billion each year, mostly from consumers. Informational, legal, and other factors suggest that original creditors should have an advantage in collecting debts owed to them. Then, why does the debt collection industry exist and why is it so large? Explanations based on economies of scale or specialization cannot address many of the observed stylized facts. We develop an application of common agency theory that better explains those facts. The model explains how reliance on an unconcentrated industry of third-party debt collection agencies can implement an equilibrium with more intense collections activity than creditors would implement by themselves. We derive empirical implications for the nature of the debt collection market and the structure of the debt collection industry. A welfare analysis shows that, under certain conditions, an equilibrium in which creditors rely on third-party debt collectors can generate more credit supply and aggregate borrower surplus than an equilibrium where lenders collect debts owed to them on their own. There are, however, situations where the opposite is true. The model also suggests a number of policy instruments that may improve the functioning of the collections market.
\end{abstract}

Keywords: Debt collection, contract enforcement, consumer credit markets, regulation of credit markets, credit cards, bank reputation, FDCPA

JEL classification: D18, G28, L24

\footnotetext{
${ }^{a}$ Assistant Professor of Finance, Bocconi University. Address: Via Roentgen 1, Milan, Italy, 20136. E-mail: viktar.fedaseyeu@unibocconi.it.

${ }^{b}$ Vice President, Federal Reserve Bank of Philadelphia. Address: Ten Independence Mall, Philadelphia, PA, 19106. E-mail: bob.hunt@phil.frb.org.

This paper has benefited from comments by Kenneth Ahern, Thomas Chemmanur, Francesco Corielli, Darren Kisgen, Marco Ottaviani, Phil Strahan, Stephanie Wilshusen, and seminar participants at Bocconi University and the Federal Reserve Bank of Philadelphia. Any remaining errors are solely attributable to the authors. The views expressed here are not necessarily those of the Federal Reserve Bank of Philadelphia or the Federal Reserve System. No statements contained in this paper should be treated as legal advice. This paper may be downloaded free of charge from the Bank's website at http://www.philadelphiafed.org/research-and-data/publications/working-papers/. Viktar Fedaseyeu thanks CAREFIN, the Center for Applied Research in Finance at Bocconi University, for financial support.
} 


\section{Introduction}

Debt collection comprises activities of creditors in the process of trying to recover the debts owed to them. It is the primary mechanism of contract enforcement in consumer credit markets and affects millions of consumers. Creditors can try to collect on their own, or they may outsource collections to third-party firms. As we show in this paper, the existence of such firms may fundamentally change the equilibrium in the credit market and affect the supply of credit and borrower welfare.

The third-party debt collection industry in the U.S. is large. In 2011, approximately 14 percent (or 30 million) of American consumers had accounts that were subject to third-party collections (Federal Reserve Bank of New York 2011). This industry recovered approximately $\$ 55$ billion from borrowers in 2010 and returned approximately 80 percent of this amount to creditors (Ernst \& Young 2012). It employs more than 140,000 people, who make more than 1 billion consumer contacts every year (Hunt 2007). Further, debt collection performed by third-party firms represents most of the debt collection activity in the U.S. ${ }^{1}$

Potential explanations for the size and importance of the third-party debt collection industry include economies of scale and specialization benefits that original creditors might not enjoy. However, in this paper, we argue that those explanations are neither necessary nor sufficient to account for a number of empirical facts about the collections market. Indeed, there are a number of reasons to think that creditors enjoy a substantial absolute advantage over third-party collectors. For example, original creditors generally have more information about the borrower than do collection firms (Thomas, Matuszyk, and Moore 2012). Second, creditors are generally less constrained by regulation than are third-party collectors in the U.S. This is because federal law, and many state laws, pertaining to debt collection explicitly exclude from their jurisdiction the activities of the original creditors collecting on debts owed to them. Third, the debt collection industry is much less concentrated and more geographically segmented than the credit card market, which is both concentrated and national in scope. The majority of collections firms employ fewer than 10 people. Thus, outsourcing debt collection to third-party agencies may not provide additional benefits from economies of scale compared with what creditors can achieve by keeping

\footnotetext{
${ }^{1}$ According to Bureau of Labor Statistics' Occupational Employment Statistics, in 2012 thirdparty debt collectors outnumbered debt collectors employed directly by financial institutions.
} 
debt collection in-house.

In this paper, we propose a complementary, but more compelling, explanation for why third-party debt collectors can create value for creditors, despite the abovementioned benefits of collecting in-house. The mechanism we propose is based on the common agency framework (Bernheim and Whinston 1985, 1986; Prat and Rustichini 2003) and essentially enables creditors to protect their relative reputations in a competitive credit market with rational borrowers. Without third-party debt collectors, creditors would be forced to collect on their own and would tend to use lenient collection practices for fear of damaging their individual reputations (which would reduce demand for their services). A third-party agency collecting on behalf of several creditors, on the other hand, may use harsher debt collection practices than the creditors would. This is because those practices will be associated with all creditors that hired this agency, in which case, borrowers cannot discriminate against individual creditors. ${ }^{2}$ As a result, all creditors that hire third-party debt collectors may have bad reputations, but no individual lender may be seen as any worse than any other individual lender.

We use the simple intuition above to show that third-party debt collection agencies can, under certain conditions, sustain an equilibrium with harsher debt collection practices than the practices that creditors use by themselves. This equilibrium generates higher profits for creditors, even when a positive fraction of those profits must be shared with the debt collection agencies. Further, using this theory, we derive a number of empirical predictions about the debt collection industry that are consistent with observed empirical facts. In particular, we show that third-party debt collectors appear to use harsher debt collection practices than original creditors and that third-party debt collection can be preferred by creditors even when the latter have informational, technological, and legal advantages in collecting from their own borrowers. We show that the equilibrium in which debt collection is outsourced to third-party firms can be supported when the debt collection industry is unconcentrated and that creditors will allocate delinquent accounts to multiple debt collection

\footnotetext{
${ }^{2}$ Unless otherwise stated, we use the terms "lenient" and "harsh" in this paper to characterize the intensity of collection efforts that are used. In our notation, harsh does not necessarily imply the use of an illegal, unfair, or deceptive practices. It might simply reflect a higher propensity to make phone calls or to obtain garnishments, for example. Below, we provide empirical evidence that is consistent with the intuition that third-party collection agencies generally employ harsher practices than do creditors.
} 
agencies. In our model, an equilibrium with a more concentrated lending market can support a more concentrated collections industry, suggesting that there might be some comovement in the market structure of these two sectors. The model also predicts that, under certain conditions, more effective debt collection will increase the supply of consumer credit, consistent with recent empirical evidence (Fedaseyeu 2013).

We also analyze the effects of third-party debt collectors on welfare. Since thirdparty debt collectors facilitate more effective collections than individual creditors are able to implement on their own, their presence can increase the supply of credit and may raise total borrower welfare under certain conditions. At the same time, there are circumstances under which the existence of third-party debt collection agencies may lower borrower welfare because of the increase in the overall harshness (and therefore disutility) of debt collection.

In terms of policy decisions, it matters significantly whether the existence of thirdparty debt collectors is driven primarily by specialization and economies of scale or by common agency considerations. If specialization is the primary driver of this industry, then policy instruments that affect third-party debt collectors will generally have a continuous effect on the intensity of debt collection activity. If the common agency argument is correct, on the other hand, then changes in regulations may lead to discontinuous changes in the intensity of debt collection activity (because the nature of the equilibrium in the credit market may change).

Our model is admittedly abstract. Nevertheless, it suggests some concrete tools that policymakers can use to influence the behavior of creditors and collection agencies. For example, licensing and liability costs established by regulation will be reflected in the fees charged to creditors as well as the market structure of the collections industry. The difference between the efficacy of harsh versus lenient collection practices can be influenced by regulations that specify what conduct is unfair, deceptive, or abusive. The government and other organizations can promote consumer education about available consumer protections, which might increase borrowers' willingness to choose their creditors based on the collections practices they employ. Improvements in information or technology may improve the efficacy of collections without necessarily increasing disutility to consumers.

The rest of this paper is organized as follows. Section 2 relates this paper to the existing literature. Section 3 presents a few stylized facts about the debt collection 
industry. Section 4 develops a theory of the debt collection industry based on the common agency framework. Section 5 describes the optimal industry structure that follows from the model developed in the previous section and deals with endogenous demand and supply of credit. Section 6 contains a welfare analysis. In Section 7, we provide empirical predictions and policy implications that follow from the model developed in this paper. Section 8 concludes. Proofs of propositions are confined to the appendix.

\section{Relation to existing literature}

In this paper, we apply the theory of common agency as developed in Bernheim and Whinston $(1985,1986)$ and extended in Prat and Rustichini (2003) to explain the economics of contract enforcement in consumer credit markets. Unlike most work on common agency, our model is concrete enough to derive testable empirical implications and analyze borrower welfare.

There is a large (mostly empirical) literature on creditor remedies, reviewed in Hunt (2007) and Hynes and Posner (2002). ${ }^{3}$ However, only a handful of papers focus on debt collection. Krumbein (1924) is the earliest such paper and provides a detailed description of the market as it existed nearly 100 years ago. This description suggests that the existence of third-party debt collection agencies cannot be explained by specialization alone. A more recent review of the institutional detail and regulation of collections is found in Hunt (2007) and a number of reports published by the Federal Trade Commission (2009, 2011a). Fedaseyeu (2013) shows that regulations of third-party debt collections affect credit supply, with more stringent regulations leading to fewer openings of new revolving lines of credit.

Several papers have established that a significant proportion of borrowers may be exposed to collections activity. For example, Dawsey and Ausubel (2004) report that in one large bank's portfolio, about half of the individuals who defaulted on their credit cards had not filed for bankruptcy at the time of their default or shortly thereafter. They describe this behavior as "informal bankruptcy." The literature has also explored the relationship between collections, default rates, and bankruptcy filing rates. White (1998) argues that many households default without filing for bankruptcy because creditors may decide not to collect on defaulting borrowers since

\footnotetext{
${ }^{3}$ See, for example, Barth, Gorur, Manage, and Yezer (1983) and Barth, Cordes, and Yezer (1986).
} 
they lack the ability to differentiate between between borrowers who will repay and those who will file for formal bankruptcy. Dawsey, Hynes, and Ausubel (2013) document that informal bankruptcy is more prevalent in states that grant consumers a private right of action against creditors who violate debt collection laws. Athreya, Sanchez, Tam, and Young (2013) develop a model with formal bankruptcy and informal default (with renegotiation) and examine borrowers' choice between the two. These are clearly important issues to examine, but they are not the focus of our paper, which addresses the underlying economic logic behind the existence of third-party debt collection agencies. Further, while our model does not address the relationship between formal and informal bankruptcy, the equilibrium outcome we describe here is affected by consumer-related regulations that influence expected recovery rates and consumer attitudes toward collections.

Our paper complements a large literature on consumer bankruptcy. This literature studies the relationship between bankruptcy and the supply and demand for credit (Gropp, Scholz, and White 1997; White 2007) as well as welfare implications of various bankruptcy regimes (Chatterjee, Corbae, Nakajima, and Ríos-Rull 2007; Livshits, MacGee, and Tertilt 2007). Since consumer bankruptcy provides borrowers with a protection mechanism, it restricts the creditors' ability to demand repayment from borrowers. The existence of third-party debt collectors, as we show in this paper, acts in the opposite direction by increasing repayment that creditors can obtain from defaulting borrowers.

Finally, there is an emerging theoretical literature that explores the effect of new technologies used in the collection process on credit supply and bankruptcy. Chatterjee (2010) develops a model to explain why many borrowers do not immediately file for bankruptcy when they default and how changes in the productivity of collections have influenced those choices over time. Drozd and Serrano-Padial (2013) show that improvements in methods of screening defaulting borrowers can reconcile the paradoxical trends in the pricing and supply of revolving credit in the U.S. However, none of this research addresses the question of why collections, of either the low or high tech variety, are delegated to third-party firms, which is the central question of this paper. 


\section{Stylized facts}

\subsection{Fact 1. Third-party debt collectors use harsher debt collection practices than} original creditors.

For credit cards, and many other consumer debts, creditors often conduct their own initial collection efforts (typically termed first-party collections), usually through the early stages of delinquency. Loans that are not being repaid are eventually removed from the balance sheet as they no longer qualify as earning assets. It is usually at this point that the account is placed for collection by third-party agencies.

We analyze the relative harshness of collections activity used by first-party and third-party collectors by examining two data sets on consumer complaints collected by the Federal Trade Commission (FTC). The first data set, called Sentinel, includes consumer complaints filed with the FTC, other state and federal agencies, Better Business Bureaus, and a number of nonprofit consumer protection organizations (Federal Trade Commission 2013). The second data set is assembled from a congressionally mandated annual report on the FTC's enforcement of the main federal law that regulates debt collection activity in the U.S., the Fair Debt Collection Practices Act (FDCPA). It includes statistics on consumer complaints filed only with the FTC (Federal Trade Commission 2011b). ${ }^{4}$

The evidence we assemble is indirect, which we recognize is imperfect. We are forced to rely on this evidence, however, since there are no direct measures of the relative harshness of collections activity used by first-party and third-party collectors. Still, this evidence suggests that third-party debt collectors are more likely to use harsher debt collection practices than original creditors. ${ }^{5}$

In Figure 1, we depict the time series of the relative intensity of complaints against first-party collectors versus third-party collectors. In order to construct the intensity

\footnotetext{
${ }^{4}$ It should be noted that while the FTC uses information in these complaints to inform its surveillance and enforcement efforts, it does not have the resources to verify the accuracy of the complaints that are filed.

${ }^{5}$ Since third-party debt collectors typically collect on charged-off accounts, it may be the case that the difference in harshness of debt collection practices used by first-party and third-party debt collectors is due in part to the difference in the types of borrowers they collect from. However, lenders choose to allocate charged-off accounts to third-party debt collectors, and this choice is endogenous. Therefore, it is likely that lenders allocate debt collection of charged-off accounts to third-party agencies because those agencies can use harsher debt collection practices and not that debt collection agencies use harsher debt collection practices because they collect on charged-off accounts.
} 
of complaints against first-party collectors, we normalize the total number of complaints attributed to first-party collectors in the FTC database by the total employment of bill and account collectors in the U.S. The intensity of complaints against third-party collectors is computed similarly, by using complaints attributed to thirdparty collectors and the employment of bill and account collectors in the Business Support Services Sector (which includes the third-party collections industry). Roughly speaking, there are 10 times more complaints per collector in the third-party collections industry than for the economy as a whole. ${ }^{6}$

\section{[INSERT FIGURE 1 ABOUT HERE]}

Other, more indirect measures also suggest that third-party collectors use harsher practices than first-party collectors. The FTC receives more complaints about the debt collection industry than about any other specific industry. From 2006 to 2012, complaints about collections activity accounted for about 9 percent of all complaints in the Sentinel database. ${ }^{7}$ According to the FTC's annual FDCPA reports, since 1999, about three-quarters of all complaints about collections activity were associated with third-party collections firms.

The notion that third-party debt collection agencies use harsher practices than the original creditors was also shared by Congress and shaped the current legal environment of debt collection in the United States. Section 803(6) of the FDCPA explicitly excludes original creditors from its definition of debt collectors. When this law was passed in 1977, the decision to exclude first-party collections from its coverage was based, in part, on testimony and congressional views that creditors were not the primary source of the abuses motivating the creation of new consumer protections. ${ }^{8}$

\footnotetext{
${ }^{6}$ It should be noted that the debt collection industry does not agree with the FTC's classification or measurement of collections complaints. See, for example, InsideArm (2012).

${ }^{7}$ In the Sentinel data, the number of recorded consumer complaints of all sorts has grown rapidly during the last decade, in part because the maturation of the Internet has reduced the costs of filing complaints. The total number of complaints increased 11 percent a year during the decade ending in 2012. Collections complaints increased slightly more rapidly at about 12 percent per year.

${ }^{8}$ For example, when reporting out of committee the bill that eventually became the Fair Debt Collections Practices Act, the Senate Committee on Banking, Housing, and Urban Affairs stated, in a section titled Need for this Legislation, "Unlike creditors, who are generally restrained by the desire to protect their good will when collecting past due accounts, independent collectors are likely to have no future contact with the consumer and often are unconcerned with the consumer's opinion of them." (U.S. Senate 1977, p. 2).
} 
The FDPCA has been reauthorized and amended several times, and this exclusion remains.

3.2. Fact 2. There are informational, technological, and legal reasons why first-party collections should be more efficient than third-party collections.

Delegating debt collection to a third party is costly for creditors. The most obvious cost that creditors have to bear when they place accounts with a third-party collection firm is that they have to share any recoveries with it. ${ }^{9}$ At the same time, outsourcing collections saves labor and other costs that would otherwise be devoted to collections in-house. All else equal, a creditor will be better off outsourcing collections if thirdparty firms are either more productive or less expensive than an internal collections process.

While the benefits to specialization for third-party collectors are almost certainly important, there are a number of reasons to think that, in the absence of reputational concerns, in-house collections may be more efficient for a majority of creditors. To begin with, creditors generally have more information about their borrowers than third-party agencies, and this information advantage can be important for the collections process (Thomas, Matuszyk, and Moore 2012). Furthermore, there is evidence suggesting that account transfers from creditors to third-party agencies can result in a significant loss of information (Federal Trade Commission 2009, 2011a). Oftentimes, debt collectors find it difficult to obtain even Social Security numbers of the debtors. ${ }^{10}$ Even though the above evidence is difficult to quantify, it does raise the question of why a creditor would attempt to transfer an account to a third party when any information loss can be avoided by collecting in-house.

It is also likely that original creditors enjoy an absolute technological advantage over most collections firms. This is because large lenders enjoy the scale necessary to invest in sophisticated computers and models, which may be prohibitively expensive for most collections firms. ${ }^{11}$ While it is true that the cost of information technology

\footnotetext{
${ }^{9}$ According to the ACA International's 2012 Benchmarking Survey, the median commission rate charged by third-party debt collectors was 26 percent (ACA International 2012).

${ }^{10} \mathrm{~A}$ collection industry consultant, Bev Evancic, noted that, "although debt collectors find SSNs [Social Security numbers] particularly helpful in identifying the correct individual debtor, creditors remain cautious about releasing this sensitive information." See Federal Trade Commission (2011a).

${ }^{11}$ For example, Chin and Kotak (2006) describe the development of a collections platform for a large credit card lender that required the efforts of 120 employees and contractors for almost a year.
} 
has fallen over time, widespread adoption of these technologies among smaller collection firms is a relatively recent phenomenon and cannot explain the substantial number of debt collection firms that has persisted during the last 40 years (see Table 1).

Finally, in the U.S., first-party party collectors are generally less constrained by regulation than are third-party collectors. This is because federal law, and many state laws, pertaining to debt collection explicitly exclude from their jurisdiction the activities of the original creditors collecting on debts owed to them. In particular, the FDCPA explicitly excludes original creditors from its definition of debt collectors. Among the state laws, approximately half (26) do not apply to the original creditors.

\subsection{Fact 3. The debt collection industry is large and yet unconcentrated.}

The debt collection industry is large. In 2010, there were about 4,200 active third-party debt collection agencies in the U.S., which employed over 140,000 people (see Table 1). The industry collected approximately $\$ 55$ billion in 2010 and returned about 80 percent of this amount to creditors (Ernst \& Young 2012).

\section{[INSERT TABLE 1 ABOUT HERE]}

Despite the large size of the debt collection industry as a whole, the majority of collection agencies are small. As recently as 2007, 90 percent of collections firms had fewer than 50 employees; 58 percent had fewer than 10 (see Table 1). In addition, concentration ratios in this industry are low. In 2007, the eight largest firms accounted for less than 25 percent of industry revenues, while the eight largest credit card issuers accounted for 87 percent of revenues.

It is also worth noting that the number of firms in this industry has been remarkably stable during the last 40 years, especially when compared with the decline in the number of banks and thrifts over this period. Important technological changes that have taken place in recent times have not yet forced the kind of consolidation observed in other areas of financial services. Since the diffuseness of the debt collection industry is an old phenomenon, technological advances, even though undoubtedly important, cannot be the primary explanation of the current industry structure. 
3.4. Fact 4. Creditors tend to allocate debt collection across many third-party agencies, and each third-party agency usually collects on behalf of several creditors.

The average collection firm serves 422 clients. Creditors, in turn, tend to allocate their accounts across multiple collection agencies. The U.S. Department of Education, for example, uses 22 debt collection agencies (Department of the Treasury 2011). In addition, creditors often move accounts that have not been liquidated from one collection firm to another. In a recent survey, 75 percent of the value of charged-off debts were placed with a first collector and 25 percent with a second or third collector (ACA International 2011). Even though we do not explicitly model reallocation of accounts here, such reallocation suggests that creditors typically use multiple collection firms at the same time.

\subsection{Fact 5. Consolidation in the debt collection industry followed consolidation in the banking industry.}

As we previously showed, the collections industry is unconcentrated. Nevertheless, its market structure has been changing over time. Between 1987 and 2007, the eightfirm concentration ratio in the debt collection industry increased from 17.2 percent to 23.1 percent. At the same time, the share of industry employment attributable to very small firms (fewer than nine employees) decreased from 20.2 percent in 1987 to 6.1 percent in 2007 . These changes occurred at a time when the banking industry experienced a period of rapid consolidation, with the eight-firm concentration ratio for the banks (as measured by credit card balances) increasing from 34.5 percent in 1987 to 78.1 percent in 2007. Thus, the moderate increase in the concentration of the debt collection industry corresponded to a period of increased concentration of consumer lending among the largest banks.

3.6. Fact 6. Some economic and regulatory factors may confer competitive benefits to smaller debt collection agencies relative to larger ones.

The combination of a large number of firms and existing regulatory constraints may confer benefits to smaller firms that are able to "fly under the radar." Any regulator is likely to find it difficult to discipline a highly diffuse industry and the FTC, traditionally the principal federal regulator of the collections industry, is more constrained than other regulators of financial services firms. The FTC is empowered to issue subpoenas and to engage in enforcement actions against collections firms 
allegedly engaged in unfair or deceptive acts or practices, as defined in the FDCPA. However, it does not have the authority to engage in regular examinations of collections firms. And, in stark contrast to most federal laws that regulate financial services offered to consumers, the FDCPA did not grant rule-making authority to the FTC or the other federal agencies tasked with enforcing the Act.

As a result, the principal tool that the FTC has used is case-by-case litigation against specific collections firms. This is an expensive and time-consuming process, which creates a natural tendency to focus resources on cases that can directly affect the largest number of consumers. During the three-year period 2010-12, the FTC participated in 15 cases against collections firms, mostly large ones. During this period, the agency received over 300,000 consumer complaints about collections firms (Dolan 2013).

It should be noted that regulation of collections firms at the federal level changed significantly with the passage of the Dodd-Frank Wall Street Reform and Consumer Protection Act in 2010. Title X of this law established the Consumer Financial Protection Bureau (CFPB) with important powers the FTC has not enjoyed. In particular, the new agency is empowered to promulgate rules that apply to collections firms. In 2012, the CFPB published a final rule establishing its authority to examine nonbank entities with more than $\$ 10$ million in annual receipts from consumer debt collection. The CFPB estimates this rule will apply to 175 companies, or 4 percent of collections firms, accounting for about 60 percent of industry revenues (Consumer Financial Protection Bureau 2012). While these developments suggest federal regulators will enjoy substantial new tools, smaller collections firms may receive less scrutiny, because they will not be subject to a regular process of examination by the CFPB.

\section{The model: Why creditors outsource debt collection}

Consider credit provision in a two-period game. There exists a continuum of borrowers of mass 1 and $N>1$ competing banks that provide credit to these borrowers. Every period, each borrower can obtain a loan from one lender (the lender doesn't have to be the same in both periods). Each period fraction $\gamma$ of borrowers default on their debts, with $0<\gamma<1$. All borrowers are charged the same interest rate, $r$, and 
each period the total demand for credit is $Q .{ }^{12} \gamma$ can be thought of as a random shock to borrowers' ability to repay (a labor income shock, for example) that is independent across the two periods: A borrower who defaulted in the first period has the same chance of defaulting in the second period as a borrower who did not default in the first period. There is no asymmetric information.

After the realization of the default shocks, each bank that collects on its own accounts decides whether to use harsh or lenient collection practices for all its delinquent borrowers. Let $h$ denote the recovery rate from harsh practices, with $0<h<1$, and $l$ denote the recovery rate from lenient practices. We assume that harsh practices are more effective, so that $0<l<h$. Additionally, we impose

$$
r(1-\gamma)-\gamma(1-h)>0
$$

If restriction (1) above is not satisfied, no credit will be provided, because banks lose more on their defaulting borrowers than they gain on their nondefaulting borrowers, even with the highest possible recovery rate.

There also exist $n \geq 1$ third-party debt collection agencies. Banks can delegate debt collection to these third-party agencies, which in return receive a fee proportional to the amount they collect from borrowers. We denote this fee by $f$, with $0<f<1$, and assume that it is the same across all agencies. Banks have a choice of whether to collect on their own or to hire an agency (or several agencies). For tractability, we assume that the bank either delegates its entire collections work to third-party agencies or collects entirely on its own: There is no partial delegation. Also for tractability, we will focus on symmetric equilibria in which all banks that decide to delegate debt collection to third-party agencies hire exactly $k$ agencies, with $k \leq n$ being the same for all banks. If a bank decides to delegate debt collection to thirdparty agencies, then each period it assigns the fraction $\frac{1}{k}$ of its delinquent borrowers to each of the $k$ debt collection agencies it hires.

If a bank collects on its own, that bank (possibly all banks) determines the harshness of debt collection practices it will use. If a bank delegates debt collection to third-party agencies, the agencies determine the harshness of debt collection practices they will use independently. We assume that once a bank delegates debt collection to

\footnotetext{
${ }^{12}$ Later in this paper, we will introduce borrower heterogeneity in terms of risk and will endogenize interest rates and the demand for credit.
} 
third-party agencies, it cannot subsequently renege on its contract with the agency by moving collections back in-house. ${ }^{13}$ We also assume that banks cannot precommit to debt collection practices ex ante (they cannot sign binding contracts with borrowers that specify whether harsh or lenient debt collection practices will be used upon default).

The game proceeds as follows. In the first period, banks extend credit and collect debts from borrowers who default (possibly via third-party agencies). In the beginning of the game, banks are indistinguishable, and we assume they borrowers equally as likely to allocate their demand to any one of them. Hence, each bank lends $\frac{1}{N} Q$. In the second period, borrowers decide how to allocate their demand across the $N$ banks by taking into account the harshness of the debt collection practices used in the previous period. Borrowers switch from banks that used harsh debt collection practices to banks that used lenient debt collection practices, according to the following algorithm. If a bank collected on its own and used lenient practices in the first period, its borrowers do not switch in the second period. If a bank collected on its own and used harsh practices in the first period, this bank's borrowers switch to a different bank with probability $\rho$ (which can be interpreted as a measure of demand elasticity or salience). ${ }^{14}$ We assume that switching borrowers are equally as likely to allocate their demand for credit among any of the remaining banks. If a bank delegated debt collection to third-party agencies and $m$ of those agencies used harsh practices while the remaining $k-m$ agencies used lenient practices, then the proportion of this bank's borrowers who switch to other banks is $\rho \frac{m}{k}$.

We will use subscripts to denote banks and superscripts to denote time. In the first period, each bank's (for example, bank $i$ 's) single-period profit is given by

$$
\pi_{i}^{1}=(1-\gamma) r \frac{1}{N} Q-\gamma\left(1-\lambda_{i}^{1}\right) \frac{1}{N} Q
$$

where $\lambda_{i}^{1}$ is the net recovery rate from bank $i$ 's delinquent borrowers in the first period, $r$ is the interest rate charged, and $\gamma$ is the proportion of borrowers that default on their debts. The first term in (2) represents profits from borrowers who do not default

\footnotetext{
${ }^{13}$ Such an outcome will arise endogenously if there exists a substantial fixed cost to reestablishing an internal collections department.

${ }^{14}$ If $\rho=1$, all borrowers switch away from banks that used harsh practices (demand is infinitely elastic); if $\rho=0$, debt collection practices used by banks are inconsequential (demand is completely inelastic with respect to this aspect of creditor behavior).
} 
(the proportion of such borrowers is given by $1-\gamma$ ). From such borrowers, each bank receives back the principal that it lent and also the accrued interest, for a net profit of $\frac{1}{N} r Q$. The second term in (2) represents the loss from borrowers who default (the proportion of such borrowers is given by $\gamma$ ). The bank loses the amount it lends net of recoveries (determined by $\lambda_{i}^{1}$ ), which reduce the total loss for the bank.

In the second period, bank $i$ 's single-period profit is given by

$$
\pi_{i}^{2}=(1-\gamma) r Q_{i}^{2}\left(\lambda_{i}^{1} ; \lambda_{-i}^{1}\right)-\gamma\left(1-\lambda_{i}^{2}\right) Q_{i}^{2}\left(\lambda_{i}^{1} ; \lambda_{-i}^{1}\right)
$$

where:

- $\lambda_{i}^{t}$ is the recovery rate from bank $i$ 's defaulting borrowers in period $t, i \in$ $\{1, \ldots, N\}, t \in\{1,2\}, \lambda_{i}^{t} \in\{l, h, h(1-f)\}$, and $\lambda_{-i}^{t}$ is the vector of the other banks' recovery rates from their delinquent borrowers in period $t$

- $Q_{i}^{2}$ is the amount of credit that borrowers demand from bank $i, i \in\{1, \ldots, N\}$, in the second period, which is determined by the debt collection practices used in the previous period (as previously described)

- $r$ is the interest rate (identical across banks)

- $\gamma$ is the proportion of borrowers who default on their debts.

The profit that accrues to debt collection agency $i$ in period $t, i \in\{1, \ldots, n\}$, $t \in\{1,2\}$, is given by

$$
f \mu_{i}^{t} q_{i}^{t}
$$

where $\mu_{i}^{t}$ is the harshness of debt collection practices chosen by agency $i$ in period $t$ and $q_{i}^{t}$ is the amount of debt allocated to agency $i$ for collection in period $t$. Banks and debt collection agencies maximize the present value of their profits. The discount rate is given by $\beta<1$.

In order for the problem that we model in this paper to be relevant, the potential loss of market share due to harsh debt collection practices must be sufficiently large relative to the immediate benefits of increased recoveries. We therefore impose

$$
\beta \rho r(1-\gamma)-\beta \rho \gamma(1-h)>\gamma(h-l)
$$


If restriction (5) is not satisfied, then using harsh practices in the first period is the dominant strategy for all banks. This condition is intuitive. The benefit from using harsh practices in the first period is that the immediate recoveries, $\gamma(h-l)$, are higher. The associated cost is the loss of market share and the associated income from interest in the second period, $\beta \rho r(1-\gamma)$. This cost is partially offset, however, by the diminished defaults a bank has to deal with in the second period: Since it provides credit to fewer borrowers, the total amount of loss due to default also goes down, by $\beta \rho \gamma(1-h)$.

The equilibrium concept that we use is the symmetric perfect Bayesian equilibrium in pure strategies. As we previously mentioned, for tractability we will focus on symmetric equilibria in which all banks that decide to delegate debt collection to third-party agencies hire exactly $k$ agencies, with $k$ being the same for all banks.

Proposition 1. Assume that $\beta \rho r(1-\gamma)-\beta \rho \gamma(1-h)>\gamma(h-l)$. Then,

(i) In the absence of third-party debt collection agencies (if all banks have to collect on their own), all banks use lenient debt collection practices in the first period.

(ii) If third-party debt collection agencies exist, then there exists a symmetric subgame perfect Nash equilibrium in pure strategies in which all banks delegate debt collection to third-party debt collection agencies and the agencies use harsh debt collection practices in both periods if the following restrictions are satisfied: ${ }^{15}$

$$
\begin{aligned}
& f<\frac{\gamma(h-l)-\beta \rho[r(1-\gamma)-\gamma(1-h)] \frac{n-k}{k}}{\gamma h(1+\beta)} \\
& \frac{n-k}{n k}<\frac{h-l}{\beta \rho h} \\
& 1-\frac{1}{n}+\frac{1}{k N}>\frac{h-l}{\beta \rho h}
\end{aligned}
$$

Part $(i)$ of Proposition 1 shows that without third-party debt collection agencies all banks use lenient debt collection practices in the first period. The intuition here is simple. Since the costs of using harsh debt collection practices in the first period outweigh the benefits, as we described in restriction (5), the dominant strategy for

\footnotetext{
${ }^{15}$ The following set of parameter values, for example, will satisfy all conditions in this proposition: $f=0.2, \beta=0.8, h=0.5, l=0.2, r=0.15, \gamma=0.1, \rho=0.8, n=40, k=35, N=20$.
} 
all banks is to use lenient practices in the first period. In essence, banks face a Prisoner's Dilemma. Hereafter, we will refer to the equilibrium described in part $(i)$ of Proposition 1 as the "undelegated equilibrium."

Part (ii) of Proposition 1 shows that when debt collection can be delegated to third-party agencies and certain conditions are satisfied, it is possible to sustain an equilibrium in which harsh debt collection practices will be used. This outcome arises in equilibrium because debt collection agencies decide on their actions after receiving assignments from banks. Whenever a third-party agency does not receive assignments from a sufficient number of banks, this agency infers that some banks decided to collect on their own and use lenient debt collection practices. This agency, therefore, starts using lenient debt collection practices itself. If a bank decides to deviate, each of the $k$ agencies this bank should have hired will switch to lenient practices. This will lower potential gains in market share for the deviating bank because the borrowers targeted for collection by those debt collection agencies will not switch their banks. When $k$ is sufficiently large relative to $n$, the overlap between banks and debt collection agencies is sufficient to make deviation unprofitable. ${ }^{16}$ Hereafter, we will refer to the equilibrium described in part (ii) of Proposition 1 as the "delegated equilibrium."

The delegated equilibrium, when it exists, is not unique. This is because the undelegated equilibrium in our model always exists. However, the total profits for the banking industry are higher in the delegated equilibrium (when it exists) than in the undelegated equilibrium. To see this, consider the first restriction in Proposition 1 , which implies that $h(1-f)>l{ }^{17}$ Thus, recoveries for the banks (and therefore their profits) are higher in the delegated equilibrium (when it exists) than in the undelegated equilibrium.

Proposition 1 shows that without third-party debt collection agencies banks will be forced to use lenient debt collection practices. When debt collection agencies exist, on the other hand, banks can increase their profits by switching to an equilibrium in which they delegate debt collection to such agencies. ${ }^{18}$ In the remainder of this

\footnotetext{
${ }^{16}$ If $k=n$, for example, then the deviating bank cannot gain any market share because all debt collection agencies switch to lenient practices once this bank starts collecting on its own. For any given set of the other parameter values, there will be a range of values of $k$ for which the delegated equilibrium exists.

${ }^{17} f<\frac{h-l}{h(1+\beta)} \Rightarrow f<\frac{h-l}{h} \Rightarrow h(1-f)>l$.

${ }^{18}$ Later in the paper, we will investigate whether borrower welfare is higher or lower in the dele-
} 
section, we investigate how the nature of the delegated equilibrium corresponds with the stylized facts that we previously documented.

Corollary 1. Third-party debt collection agencies use harsher debt collection practices than banks.

Corollary 1 follows from comparing part $(i)$ to part (ii) in Proposition 1. When banks collect on their own, they use lenient practices in the first period. When they hire third-party debt collection agencies, those agencies use harsh debt collection practices in the first period. Thus, our model is consistent with the existing empirical evidence (stylized fact 1) that suggests that debt collection practices used by thirdparty agencies are harsher than those used by original creditors.

Our model is consistent with the other stylized facts that we discussed in section 3. In order to show this, we will analyze the restrictions specified in part ( $i i)$ of Proposition 1. The first restriction ensures that banks do not have an incentive to deviate from the delegated equilibrium by collecting on their own and using lenient debt collection practices; for this to be the case, the fee charged by debt collection agencies must be sufficiently small. The second restriction ensures that debt collection agencies use harsh collection practices as long as banks don't deviate from the delegated equilibrium; to this end, the difference in recovery rates between harsh and lenient practices must be sufficiently large. The third restriction ensures that agencies switch to lenient debt collection practices when they observe a bank deviate from the delegated equilibrium; to this end, the difference in recovery rates between harsh and lenient practices should not be so large that agencies keep using harsh debt collection practices even if they observe one of the banks deviating from the delegated equilibrium. ${ }^{19}$

Corollary 2. In order to sustain the delegated equilibrium, the fee charged by thirdparty agencies must be sufficiently small.

Corollary 2 is intuitive and follows from analyzing the first restriction in Proposition 1 (notice that because of restriction (5) the left-hand side of this inequality

\footnotetext{
gated equilibrium than in the undelegated equilibrium.

${ }^{19}$ The intuition behind this restriction is that by using harsh debt collection practices agencies increase their recoveries but lose revenue due to borrowers switching to the deviating bank. This loss of market share is smaller if the number of banks is larger and if each bank allocates its debt collection to a greater number of debt collection agencies (in essence, in this case, each individual bank is relatively less important for the agencies that it hires).
} 
is decreasing in $\rho$ ). If the fee charged by third-party debt collection agencies is too large, then the gain from them using harsh collection practices is outweighed by the payment that banks have to give to the agencies they hire. Since $f>0$, we implicitly assume that banks have cost advantages over third-party debt collection agencies (as the former wouldn't have to incur this fee had they not used the latter). In other words, the delegated equilibrium can exist even when informational, technological, and legal factors might suggest that the original creditors would be more efficient than third-party agencies. Thus, our model incorporates the possibility that outsourcing debt collection may create inefficiencies but may still be economically viable as long as these inefficiencies are outweighed by the benefits from protecting creditors' relative reputations. ${ }^{20}$

Our model is also consistent with the fact that the debt collection industry is large but unconcentrated (large $n$ ) and that individual creditors employ multiple debt collection agencies $(k>1)$. This happens as long as there is sufficient overlap between third-party debt collection agencies and banks.

Corollary 3. In order to sustain the delegated equilibrium, the number of agencies that each bank hires, $k$, must be sufficiently close to the total number of third-party agencies, $n$.

Corollary 3 follows from analyzing the first two restrictions in Proposition 1: For any given $n$, if those restrictions hold for some $k=k^{*}$, then they will necessarily hold for any $k>k^{*}$. Intuitively, this means that in order to sustain the delegated equilibrium, there must be a sufficient degree of overlap between banks and debt collection agencies. Consider two extreme cases: The first case is when each bank hires one, and only one, debt collection agency (there is no overlap between banks and agencies). This situation is equivalent to each bank collecting on its own (apart from having to pay a fee to the agency). Hence, once a bank deviates by using lenient debt collection practices, debt collection agencies hired by other banks do not respond by

\footnotetext{
${ }^{20}$ Note that introducing efficiency gains from outsourcing debt collection to third-party agencies will make the delegated equilibrium only more beneficial for banks. Formally, assume that banks incur a cost $c$ if they collect in-house. If $c>f$, then there are direct efficiency gains from outsourcing collection to third-party agencies. In this case, the net recovery rate for the banks will be $\lambda(1-c)$ if they collect in-house, and $\lambda(1-f)$ if they delegate debt collection to third-party agencies. Thus, for any $\lambda \in\{h, l\}$, the banks would prefer to delegate debt collection to third-party agencies. If $c<f$, then collecting in-house is more efficient for the banks than delegating to third-party agencies. We implicitly assume the latter case, because in our setting $c=0$, while $f>0$.
} 
adjusting their debt collection practices, and therefore the deviating bank will be able to capture a relatively large share of switching borrowers. In this case (when $k=1$ ), the delegated equilibrium will not exist. The second case is when each bank hires all debt collection agencies $(k=n)$. This situation ensures a complete overlap between banks and debt collection agencies. Thus, once a bank deviates by using lenient practices, all debt collection agencies start using lenient practices as well, and hence, there is no loss of market share for the other banks in the second period. Therefore, it is more likely that the delegated equilibrium can be sustained in this case (when $k=n)$.

Our model is also consistent with the joint evolution of the debt collection industry and the banking industry.

Corollary 4. If the banking industry becomes more concentrated, then the delegated equilibrium can be sustained with a more concentrated debt collection industry.

Corollary 4 follows from analyzing the last restriction in Proposition 1. When $N$ (the number of banks) decreases, then this restriction can hold for a smaller $n$ (number of debt collection agencies). Of course, it will hold even if the number of debt collection agencies remains unchanged. However, it would not necessarily hold if the number of debt collection agencies decreased while the number of banks remained the same. Thus, the debt collection industry doesn't have to become more concentrated when the banking industry becomes more concentrated, but concentration in the banking industry creates conditions for the debt collection industry to become more concentrated as well. This is consistent with empirical evidence (stylized fact 5), which shows that the concentration ratios of the two industries comove but that the pace of concentration in the debt collection industry is much slower than in the banking industry.

The next corollary is not directly related to the empirical evidence we presented in Section 3. However, it suggests an important implication for policy.

Corollary 5. The delegated equilibrium is easier to sustain if the banking industry is more concentrated.

Corollary 5 follows from analyzing the last restriction in Proposition 1: If this restriction holds for some $N=N^{*}$, then it will hold for any $N<N^{*}$. Intuitively, if the number of banks decreases, each bank's share in the debt collection agencies' 
revenues increases. As a result, debt collection agencies will be more sensitive to deviations by individual banks and will therefore be more likely to enforce the delegated equilibrium. It follows from this corollary that regulators who set out to discipline the debt collection industry may find it more difficult to do so if the banking industry becomes more concentrated.

\section{Extensions}

\subsection{Optimal number of debt collection firms}

The previous corollaries provide some interesting implications for the functioning of the debt collection industry. They have little to say, however, about how the number of debt collection firms and their size are determined. Admittedly, our model is too stylized to accommodate the various nuances of the industrial structure of the debt collection industry, which are beyond the scope of this paper. However, we can show that the nature of the delegated equilibrium can influence the average size of debt collection firms and therefore their number. Thus, we can provide a rationale for why the large and unconcentrated debt collection industry (observed in the real world) may in fact be optimal (e.g., profit maximizing) from the standpoint of creditors. To do this, we will assume that the harshness of debt collection practices that third-party debt collection agencies can implement depends on the resources that regulators can spend on disciplining them. In particular, we assume that regulators can allocate a fixed budget, $G$, on disciplining all $n$ debt collection agencies. Hence, the resources allocated to disciplining each individual agency are $G / n$. We will further assume that the harshness of debt collection practices is negatively related to the resources allocated to disciplining each individual agency: $h$ is a monotonically decreasing function of $G / n$.

Proposition 2. For a given $G$, there exists a value of $n$ (the number of third-party debt collection agencies) that maximizes banks' profits. ${ }^{21}$

The intuition behind Proposition 2 is that debt collection firms must be small enough to be effective (consistent with stylized fact 6) but large enough so that

\footnotetext{
${ }^{21}$ Under certain parameter values, the value of $n$ that maximizes banks' profits is infinite. This, of course, is the result of our assumption that hiring third-party agencies is costless. This outcome can be avoided if one assumes that there is a fixed cost to hiring a third-party debt collection agency.
} 
there is sufficient overlap between banks and third-party agencies to ensure that the delegated equilibrium exists. The number of debt collection firms that balances these two goals maximizes banks' profits. Thus, our simple model is both consistent with observed empirical evidence and can help explain why the large number of small debt collection firms that we observe empirically may benefit creditors.

\subsection{Endogenous demand and supply of credit}

Thus far, we have assumed fixed demand and supply of credit. In this section, we will relax this assumption. As before, we assume that there is mass 1 of borrowers. Each borrower's demand is normalized to 1. Unlike before, we now assume that borrowers differ in their probabilities of default, $\gamma$, which is uniformly distributed between 0 and $1 .^{22}$ There is no private information, and each borrower's default probability is observable: The borrower and the banks know it. Consumers borrow in order to finance consumption, which they value. At the same time, interest payments and collection actions by creditors lower utility. We capture these ideas in the following affine form of borrowers' expected utility:

$$
U(\gamma)=1-r(1-\gamma)-\theta \hat{\lambda} \gamma
$$

where $\hat{\lambda}$ is the harshness of collection efforts that the borrower faces, $\hat{\lambda} \in\{l, h\}$. The first term in (6) represents utility from obtaining credit that is used to buy an additional unit of consumption good. With probability $1-\gamma$, the borrower makes the interest payment on the loan, which is the interest cost of obtaining credit, given by the second term in (6). The third term in (6) represents the disutility from a possible collection action on behalf of creditors, which happens with probability $\gamma$. This disutility arises for two reasons, one pecuniary and one non-pecuniary. The pecuniary disutility is due to the fact that consumption will be reduced by the amount that creditors can recover. The non-pecuniary disutility arises because borrowers may dislike being exposed to collections activity, and we capture the degree of this dislike by parameter $\theta \geq 0 .{ }^{23}$ Borrowers demand credit as long as their expected utility is nonnegative.

\footnotetext{
${ }^{22}$ The likelihood of default is independent across the two periods, as before.

${ }^{23}$ If borrowers benefit from the delay in repayment, then $\theta<1$. If, on the other hand, borrowers experience substantial non-pecuniary losses from exposure to collections activity, then $\theta>1$. The latter interpretation is consistent with the "lost value hypothesis" in Leff (1970).
} 
We endogenize interest rates in a way that ensures that banks earn positive profits. We do so because assuming that competition drives banks' profit to zero will eliminate their incentives to be concerned about their market share and therefore reputation. We model these positive profits as a markup above the break-even interest rates that would be charged in a perfectly competitive environment.

Under perfect competition, the interest rate charged by the banks (derived from their break-even condition) would be:

$$
r(1-\gamma)-\gamma(1-\lambda)=0 \Rightarrow r=\frac{\gamma(1-\lambda)}{1-\gamma},
$$

where $\lambda$, as before, is the net recovery rate for banks.

Instead, we assume that the interest rate that the banks charge borrowers is higher than the interest rate charged in a fully competitive environment by the factor $\alpha$, where $\alpha>1$. Therefore, the interest rate that borrowers with default probability $\gamma$ are charged is given by

$$
r=\alpha \frac{\gamma(1-\lambda)}{1-\gamma}
$$

Equation (8) can be rewritten as

$$
\gamma=\frac{r}{r+\alpha(1-\lambda)}
$$

For a given level of interest rates, riskier borrowers are able to obtain credit when the effectiveness of debt collection practices goes up ( $\lambda$ increases). In other words, credit supply increases when debt collection is more effective. Thus, our setup in this section is consistent with the empirical evidence in Fedaseyeu (2013).

We can now rewrite borrower utility by substituting (8) for the interest rate in (6) to obtain:

$$
U(\gamma)=1-\alpha \gamma(1-\lambda)-\theta \hat{\lambda} \gamma
$$

where $\hat{\lambda}$ is the harshness of collection efforts that the borrowers face and $\lambda$ is the recovery rate for creditors (net of fees charged by third-party collectors, if any). Note that while utility is declining in the lender markup, the effect of harshness of collection practices on utility is ambiguous. On the one hand, harsher debt collection practices 
increase recovery rates and therefore reduce the interest rate charged, and this will be reflected in the second term in (10). On the other hand, harsher debt collection practices increase the disutility associated with collections, and this will be reflected in the third term in (10).

Borrowers will be willing to obtain credit as long as their expected utility is nonnegative. Since $\lambda<1$, borrowers' utility is a decreasing function of $\gamma$ : Borrowers with higher default probabilities obtain lower utility from borrowing than borrowers with lower default probabilities. Let $\gamma_{d}$ denote the default probability of the marginal borrower who will demand credit. It is determined by the following condition:

$$
1-\alpha \gamma_{d}(1-\lambda)-\theta \hat{\lambda} \gamma_{d}=0 \Rightarrow \gamma_{d}=\frac{1}{\alpha-\alpha \lambda+\theta \hat{\lambda}}
$$

All borrowers whose probability of default lies between 0 and $\gamma_{d}$ will demand credit (and each of those borrowers will demand one unit of credit by assumption). It is clear from (11) that the effect of debt collection practices on demand depends on the magnitude of borrowers' disutility from collections. On the one hand, more effective debt collection lowers interest rates, which makes credit more attractive to borrowers. On the other hand, more effective debt collection directly reduces borrowers' utility. The demand will rise or fall depending on which of these two effects dominates. ${ }^{24}$

We can now show that the delegated equilibrium we described in Proposition 1 exists under very similar conditions as before.

Proposition 3. Assume that $\beta \rho(\alpha-1)(1-h)>h-l$ and $\beta \rho(\alpha-1)(1-h) \frac{(\alpha+(\theta-\alpha) l)^{2}}{(\alpha+(\theta-\alpha) h)^{2}}>$ $h-l$. Then,

(i) In the absence of third-party debt collection agencies (if all banks have to collect on their own), all banks use lenient debt collection practices in the first period.

(ii) If third-party debt collection agencies exist, then there exists a symmetric subgame perfect Nash equilibrium in pure strategies in which all banks delegate debt collection to third-party debt collection agencies and the agencies use harsh debt

\footnotetext{
${ }^{24}$ In our setting with linear utility, one of these two effects will always dominate for any given set of parameter values. This is unlikely to hold more generally.
} 
collection practices in both periods if the following restrictions are satisfied: ${ }^{25}$

$$
\begin{aligned}
& f<\frac{h-l-\beta \rho[(\alpha-1)(1-h)+\alpha h f] \frac{n-k}{k}}{h(1+\beta)} \\
& \frac{n-k}{n k}<\frac{h-l}{\beta \rho h} \\
& 1-\frac{1}{n}+\frac{1}{k N}>\frac{h-l}{\beta \rho h} .
\end{aligned}
$$

\section{Welfare analysis}

We now apply the analysis of endogenous supply and demand developed in the previous section to borrower welfare. Given the results of Proposition 3, our purpose is to compare borrower welfare in two possible equilibria: the one in which banks coordinate via debt collection agencies (the delegated equilibrium) and the one in which all banks collect on their own and use lenient debt collection practices (the undelegated equilibrium).

First consider the delegated equilibrium. In both periods, banks delegate debt collection to third-party agencies, which use harsh debt collection practices in both periods. In this equilibrium, borrowers whose probability of default lies between 0 and $\frac{1}{\alpha-\alpha h(1-f)+\theta h}$ will obtain credit in both periods. Therefore, total borrower welfare is given by

$$
(1+\beta) \int_{0}^{\frac{1}{\alpha-\alpha h(1-f)+\theta h}}[1-\gamma(\alpha-\alpha h(1-f)+\theta h)] d \gamma .
$$

Total borrower welfare in the delegated equilibrium (denoted $W_{d}$ ) can be expressed as:

$$
W_{d}=\frac{1+\beta}{2(\alpha-\alpha h(1-f)+\theta h)} .
$$

It is immediately clear that borrower welfare is falling in the lender markup, the fees charged by third-party collectors, and the disutility associated with collections activity. If $\alpha(1-f)>\theta$, then borrower welfare is increasing in the harshness of collections, and the reverse is true if $\alpha(1-f)<\theta$. In other words, the change in borrower welfare associated with harsher collection practices is positive if the effect of reduced interest rates dominates the higher disutility and is negative otherwise.

\footnotetext{
${ }^{25}$ The following set of parameter values, for example, will satisfy all conditions in this proposition: $f=0.2, \beta=0.8, \alpha=2, \theta=0.3, h=0.5, l=0.2, \rho=0.8, n=40, k=35, N=20$.
} 
Now consider the undelegated equilibrium. We assume that all conditions specified in Proposition 3 are satisfied, and therefore all banks use lenient debt collection practices in the first period. At the same time, using harsh debt collection practices in the second period is the dominant strategy for all banks. ${ }^{26}$ As a result, credit demand will be different between the two periods (since borrowers face different collection practices and different interest rates across the two periods).

In the first period of the undelegated equilibrium, $\lambda=\hat{\lambda}=l$. Hence, the probability of default for the marginal borrower who obtains credit in the first period is given by

$$
\gamma_{d}^{1}=\frac{1}{\alpha+(\theta-\alpha) l}
$$

In the second period of the undelegated equilibrium, all banks use harsh debt collection practices $(\lambda=\hat{\lambda}=h)$. Borrowers understand this, and therefore the probability of default for the marginal borrower who obtains credit in the second period is given by

$$
\gamma_{d}^{2}=\frac{1}{\alpha+(\theta-\alpha) h}
$$

Total borrower welfare in the undelegated equilibrium (denoted $W_{u}$ ) is given by:

$$
W_{u}=\int_{0}^{\gamma_{d}^{1}} U(\gamma) d \gamma+\beta \int_{0}^{\gamma_{d}^{2}} U(\gamma) d \gamma
$$

After some algebra, this can be rewritten as:

$$
W_{u}=\frac{1}{2(\alpha+(\theta-\alpha) l)}+\frac{\beta}{2(\alpha+(\theta-\alpha) h)} .
$$

As was the case for the delegated equilibrium, borrower welfare is falling in the lender markup, the fees charged by third-party collectors, and the non-pecuniary disutility associated with collections activity. If $\alpha(1-f)>\theta$, then borrower welfare is increasing in the harshness of collections, and the reverse is true if $\alpha(1-f)<\theta$.

Two important observations follow from this analysis. First, it is straightforward to see that borrower welfare in both the delegated and the undelegated equilibrium declines when $\theta$ increases. This implies that one way to increase borrower welfare is to

\footnotetext{
${ }^{26}$ This is admittedly a limitation of the two period set-up of our model, as it tends to reduce the difference in welfare calculated in the delegated and undelegated equilibrium.
} 
lower $\theta$, the disutility from collections, without reducing their effectiveness. Further, total borrower welfare in the delegated equilibrium can be higher or lower than in the undelegated equilibrium, depending on parameter values. Thus, eliminating the delegated equilibrium might raise or lower borrower welfare.

Proposition 4. Borrower welfare in the delegated equilibrium can be higher or lower than borrower welfare in the undelegated equilibrium, depending on parameter values.

Proposition 4 formalizes a simple intuition. The harshness of debt collection practices affects borrower welfare in two ways. On the one hand, using harsher collection practices reduces interest rates at which borrowers can obtain credit and increases credit supply. This is because harsher collection practices imply higher recovery rates, which makes banks more willing to lend in the first place. On the other hand, using harsher debt collection practices increases borrower disutility from collections. The impact of harsh collections on welfare is ambiguous and depends on the relative magnitudes of these two effects.

\section{Empirical and policy implications}

While admittedly abstract, the model developed in this paper fits many of the stylized facts of the U.S. consumer collections market better than a theory based solely on efficiencies from specialization. Further, the model can be useful for thinking about the design of more effective and efficient regulation of collections. We highlight these aspects of our paper below, starting with empirical predictions and concluding with policy implications.

(i) Debt collection industry and creditor behavior: The model in this paper provides a rationale for the existence of third-party debt collectors. Despite the costs associated with outsourcing debt collection to third parties, such outsourcing may protect relative reputations of individual lenders and raise aggregate profit in the credit industry. Our model shows that in this case, the third-party agencies can and will use harsher debt collection practices than creditors collecting on their own. ${ }^{27}$

(ii) Individual creditors are likely to hire multiple third-party agencies: When the debt collection industry is unconcentrated, sufficient overlap in the placement of collection accounts ensures that no individual creditor can deviate from the delegated

\footnotetext{
${ }^{27} \mathrm{~A}$ theory based solely on an efficiency advantage enjoyed by third-party firms can explain outsourcing of collections, but it would not explain the difference in collection tactics.
} 
equilibrium without losing market share. Thus, in equilibrium, each creditor will use multiple debt collection agencies. In reality, contracting with multiple agencies is likely to involve some additional costs for creditors. Nevertheless, so long as those costs are relatively small, the benefits offered to creditors from the delegated equilibrium can offset the incremental costs of using multiple agencies.

(iii) Number of debt collection firms and banks' profits: In an environment where a regulator allocates limited resources to supervise a diffuse industry, lender profits will likely be higher when there are many debt collection firms. This follows if additional supervisory resources relative to the number of firms tends to reduce the harshness of collections activity. This would be consistent with the intuition that smaller collection agencies may be able to "fly under the radar," implementing harsher collection practices that yield higher recovery rates.

(iv) The debt collection industry can become more concentrated when the banking industry becomes more concentrated: With fewer banks, a smaller number of debt collection agencies will suffice to achieve the overlap necessary to sustain the delegated equilibrium.

(v) Effective debt collection expands credit supply: Lenders will extend credit to riskier borrowers when expected recoveries after default compensate for the higher default probability. Risky borrowers will demand credit if a consequence of more effective collections practices is a sufficiently large reduction in interest rates.

(vi) Borrower welfare: An important explanation for the existence of third-party collections is that lenders desire to protect their reputation, and this can occur in a market equilibrium that exhibits common agency. In this framework, borrower welfare may be higher or lower in a credit market with delegated collections as compared to one in which creditors collect only in-house. The determination of which is superior, from the standpoint of borrowers, is largely an empirical question.

(vii) The effect of policy instruments: Understanding the economics of the debt collection market is important for policy decisions. In a market explained solely by specialization, incremental policy reforms are likely to have continuous effects on outcomes (either increasing or decreasing total collections activity or changing the proportions of first- and third-party collections, for example). This is not necessarily the case for a market based on common agency, since policy changes may result in discontinuous shifts in the market and may even eliminate the delegated equilibrium altogether. 
Our model suggests several means of influencing the likelihood that creditors will delegate collections to third parties. These include changing the difference in recovery rates associated with harsh and lenient collections $(h-l)$ or raising third-party collections costs (which would likely increase $f$ ). A key factor that explains the willingness of creditors to delegate collections is the degree to which borrowers will punish them for using more harsh collection practices than their competitors ( $\rho$ in the model). This is a factor that might be influenced through borrower education, better disclosures, and rules governing the collection process that are more transparent to the borrower.

The model illustrates one of the core trade-offs that must be considered when designing the rules of contract enforcement for unsecured credit. On the one hand, increased efficacy of collections increases recoveries. This, in turn, should expand the supply of credit. The strength of this effect will depend on the degree of competition in the loan market. On the other hand, increased recoveries associated with heightened collection efforts imposes pecuniary and non-pecuniary costs on borrowers. The net of these effects determines the change in demand for credit and the resulting welfare for borrowers.

This trade-off can be relaxed, however, to the extent that the policymakers can reduce the non-pecuniary disutility of collections imposed on borrowers. For example, better and more verifiable information about the income and liquidity of borrowers might lead to more focused and effective collections (Drozd and Serrano-Padial 2013). In the model, this might be reflected by changes that lower $\theta$.

\section{Conclusion}

We study the economics of contract enforcement in consumer credit markets and show that outsourcing debt collection to third-party agencies can create value for creditors, despite the costs associated with transferring accounts for collection from original creditors to debt collectors. We develop a model along the lines of the common agency theory with multiple principals and multiple agents and show that it can explain a number of empirical facts about the debt collection industry. We show that third-party agencies use harsher collection practices than original creditors, consistent with the behavior we observe in the data. When multiple creditors hire multiple third-party agencies, each creditor must hire a sufficient number of debt collection agencies, which explains the usual practice of having multiple agencies collect on behalf of the same creditor. We then show that the structure of the banking industry 
affects the size of debt collection agencies: Consolidation in the collections industry follows consolidation in the banking industry, consistent with the recent evolution of both industries. We also show that there exists an optimal number of debt collection firms (in the sense of maximizing lender profits), which may explain why the industry is still decentralized. The model shows that more effective debt collection increases the supply of unsecured consumer credit. By analyzing conditions under which a sustainable equilibrium with debt collection agencies exist, we provide possible tools for policymakers to influence the economics of contract enforcement in consumer credit markets. Our welfare analysis suggests that, under certain conditions, an equilibrium in which creditors rely on third-party debt collectors can result in more credit and aggregate consumer surplus than an equilibrium where lenders collect debts owed to them on their own. There are, however, situations where the opposite is true. The model also suggests a number of policy instruments that may improve the functioning of the collections market.

\section{References}

ACA International. 2011 Top Collections Market Survey, For period: Jan 1, 2010-Dec 21, 2010. Minneapolis: ACA International, 2011.

ACA International. 2012 Agency Benchmarking Survey, For period: Jan 1, 2011-Dec 21, 2011. Minneapolis: ACA International, 2012.

Kartik Athreya, Juan M. Sanchez, Xuan Tam, and Eric R. Young. Bankruptcy and Delinquency in a Model of Unsecured Debt. Working Paper 2012-042B, Federal Reserve Bank of St. Louis, 2013.

James R. Barth, Padma Gorur, Neela Manage, and Anthony M. J. Yezer. The Effect of Government Regulations on Personal Loan Markets: A Tobit Estimation of a Microeconomic Model. Journal of Finance, 38(4):pp. 1233-1251, 1983.

James R. Barth, Joseph J. Cordes, and Anthony M. J. Yezer. Benefits and Costs of Legal Restrictions on Personal Loan Markets. Journal of Law and Economics, 29 (2):pp. 357-380, 1986.

B. Douglas Bernheim and Michael D. Whinston. Common Marketing Agency as a Device for Facilitating Collusion. RAND Journal of Economics, 16(2):pp. 269-281, 1985. 
B. Douglas Bernheim and Michael D. Whinston. Common Agency. Econometrica, 54(4):pp. 923-942, 1986.

Satyajit Chatterjee. An Equilibrium Model of the Timing of Bankruptcy Filings. Mimeo, Federal Reserve Bank of Philadelphia, 2010.

Satyajit Chatterjee, Dean Corbae, Makoto Nakajima, and José-Víctor Ríos-Rull. A Quantitative Theory of Unsecured Consumer Credit with Risk of Default. Econometrica, 75(6):pp. 1525-1589, 2007.

Amita Goyal Chin and Hiren Kotak. Improving Debt Collection Processes Using Rule-Based Decision Engines: A Case Study of Capital One. International Journal of Information Management, 26(1):pp. 81-88, 2006.

Consumer Financial Protection Bureau. Defining Larger Participants of the Consumer Debt Collection Market. Federal Register, 77(211):pp. 65775 - 65799, 2012.

Amanda E. Dawsey and Lawrence M. Ausubel. Informal Bankruptcy. Working paper, University of North Carolina Greensboro and University of Maryland, 2004.

Amanda E. Dawsey, Richard M. Hynes, and Lawrence M. Ausubel. The Regulation of Non-Judicial Debt Collection and the Consumer's Choice among Repayment, Bankruptcy and Informal Bankruptcy. American Bankruptcy Law Journal, 87: 1-26, 2013.

Department of the Treasury. U.S. Government Receivables and Debt Collection Activities of Federal Agencies. Fiscal Year 2010 Report to the Congress, Department of the Treasury, Financial Management Service, Washington, D.C., March 2011.

James Reilly Dolan. Prepared Statement of the Federal Trade Commission Before Senate Committee on Banking, Housing, and Urban Affairs, Subcommittee on Financial Institutions and Consumer Protection, United States Senate. Washington, D.C., July 17, 2013.

Lukasz A. Drozd and Ricardo Serrano-Padial. Modeling the Credit Card Revolution: The Role of Debt Collection and Informal Bankruptcy. Working Paper 13-12, Federal Reserve Bank of Philadelphia, April 2013. 
Ernst \& Young. The Impact of Third-Party Debt Collection on the National and State Economies. Technical report, Ernst \& Young, 2012.

Viktar Fedaseyeu. Debt Collection Agencies and the Supply of Consumer Credit. Working paper 13-38, Federal Reserve Bank of Philadelphia, September 2013.

Federal Reserve Bank of New York. Quarterly Report on Household Debt and Credit. Technical report, Federal Reserve Bank of New York, New York, NY, Q4 2011.

Federal Trade Commission. Collecting Consumer Debts: The Challenges of Change. Report, Federal Trade Commission, Washington, D.C., February 2009.

Federal Trade Commission. Repairing A Broken System: Protecting Consumers in Debt Collection Litigation and Arbitration. Report, Federal Trade Commission, Washington, D.C., July 2011a.

Federal Trade Commission. Annual Report 2011: Fair Debt Collection Practices Act. Technical report, Federal Trade Commission, Washington, D.C., March 2011b.

Federal Trade Commission. Consumer Sentinel Network Data Book. Report, Federal Trade Commission, Washington, D.C., 2013.

Reint Gropp, John Karl Scholz, and Michelle J. White. Personal Bankruptcy and Credit Supply and Demand. Quarterly Journal of Economics, 112(1):pp. 217-251, February 1997.

Robert Hunt. Collecting Consumer Debt in America. Business Review, Federal Reserve Bank of Philadelphia, Q2:pp. 11-24, 2007.

Richard Hynes and Eric A. Posner. The Law and Economics of Consumer Finance. American Law and Economics Review, 4(1):pp. 168-207, 2002.

InsideArm. FTC Debt Collection Complaints Compendium. Q1, 2012.

William C. Krumbein. Collection Agencies. University Journal of Business, 3(1):pp. 48-67, December 1924.

Arthur Allen Leff. Injury, Ignorance and Spite-The Dynamics of Coercive Collection. Yale Law Journal, 80(1):pp. 1-46, November 1970. 
Igor Livshits, James MacGee, and Michéle Tertilt. Consumer Bankruptcy: A Fresh Start. American Economic Review, 97(1):pp. 402-418, March 2007.

Andrea Prat and Aldo Rustichini. Games Played Through Agents. Econometrica, 71 (4):pp. 989-1026, July 2003.

L.C. Thomas, A. Matuszyk, and A. Moore. Comparing Debt Characteristics and LGD Models for Different Collections Policies. International Journal of Forecasting, 28 (1):pp. 196-203, January 2012.

U.S. Senate. Fair Debt Collection Practices Act. Senate Report 95-382, U.S. Senate, Committee on Banking, Housing and Urban Affairs, Washington, D.C.: Government Printing Office, 1977.

Michelle J. White. Why Don't More Households File for Bankruptcy? Journal of Law Economics and Organization, 14(2):pp. 205-231, 1998.

Michelle J. White. Bankruptcy Reform and Credit Cards. Journal of Economic Perspectives, 21(4):pp. 175-200, Fall 2007. 
Figure 1: Consumer complaints against first-party and third-party debt collectors. The number of complaints per 100 collectors is depicted on the vertical axis. Year is depicted on the horizontal axis.

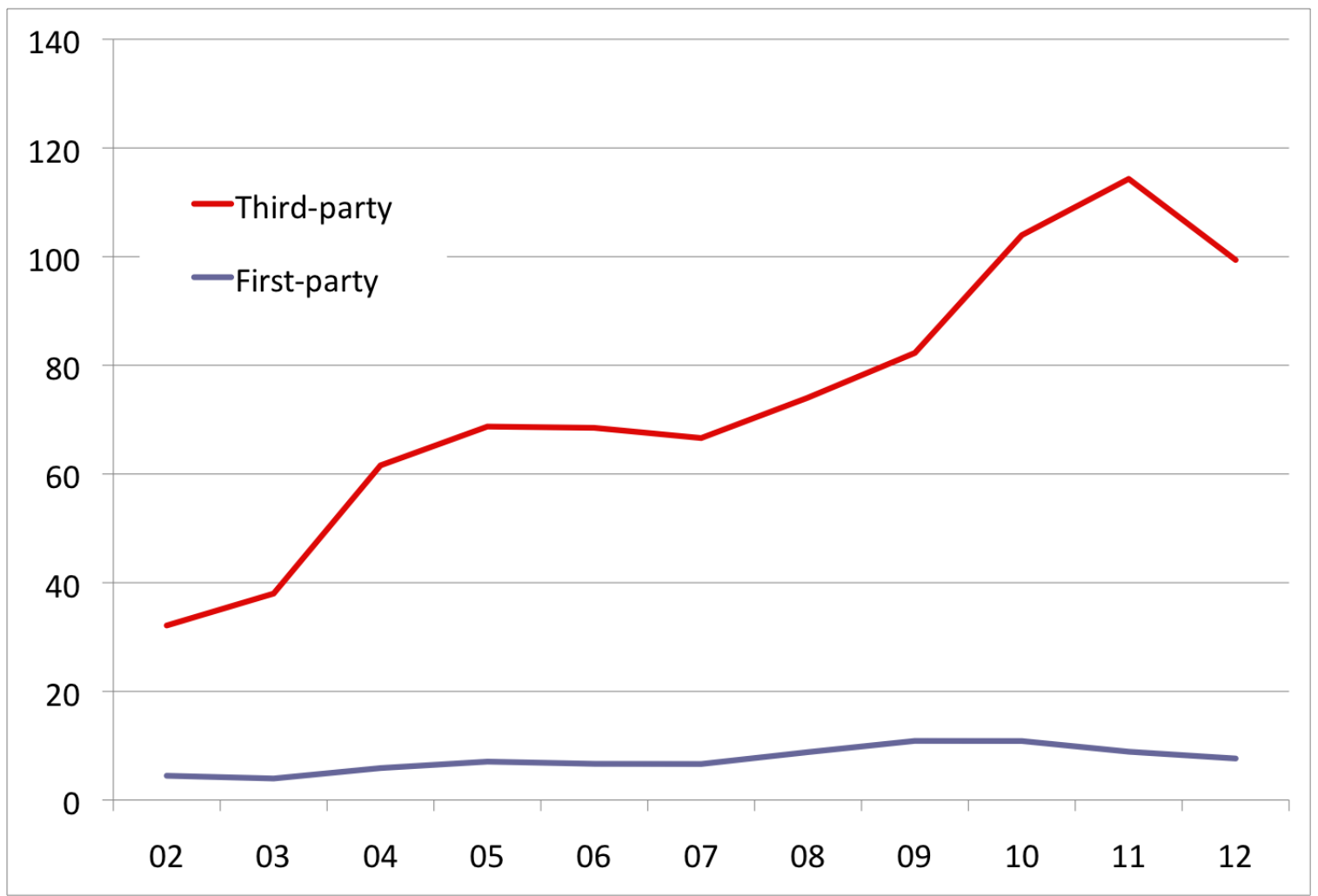

Sources: Federal Trade Commission Annual FDCPA Reports; U.S. Bureau of Labor Statistics, Occupational Employment Survey 


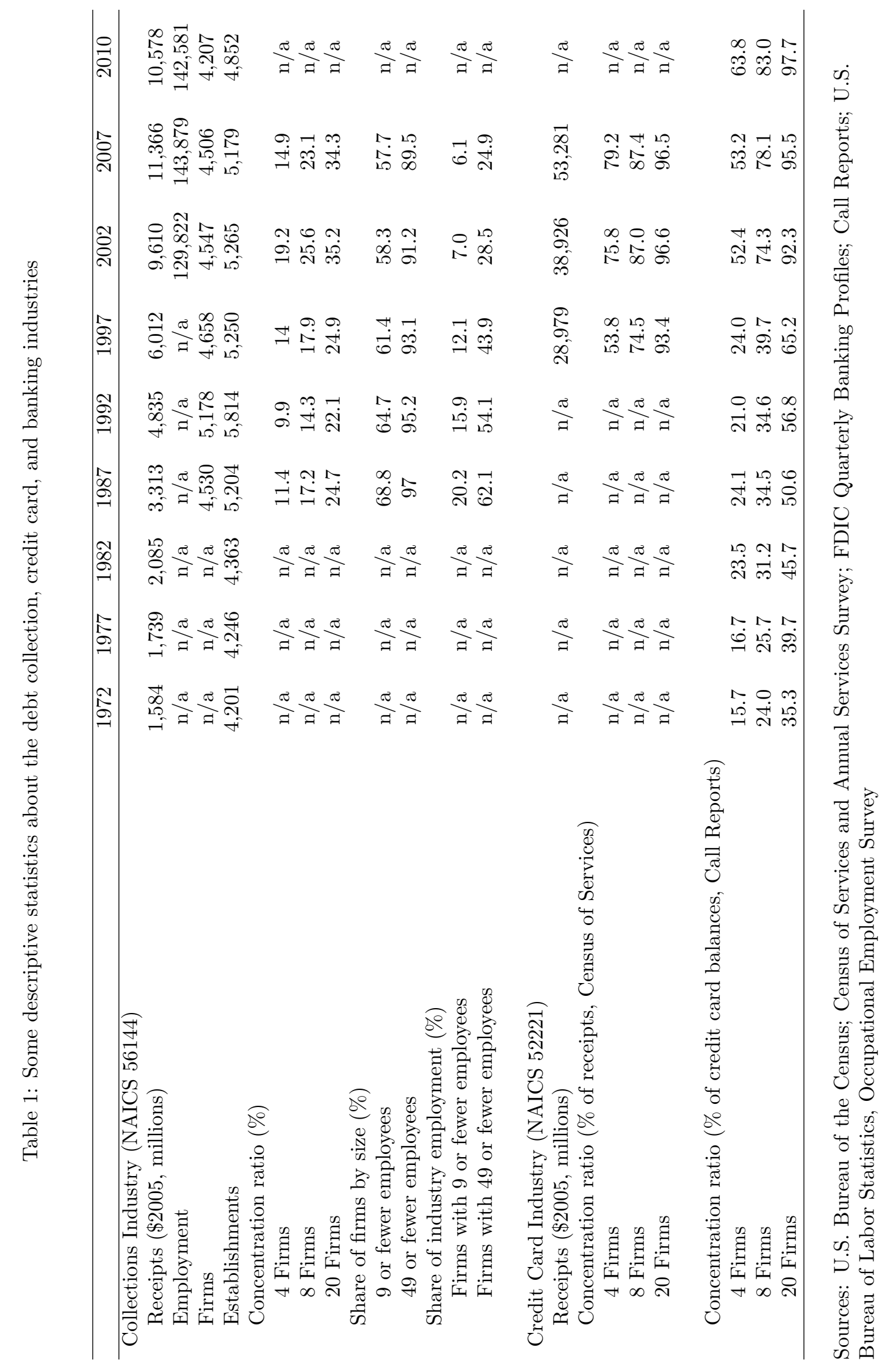




\section{Appendix A. Proofs of Propositions}

Proposition 1. Assume that $\beta \rho r(1-\gamma)-\beta \rho \gamma(1-h)>\gamma(h-l)$. Then,

(i) In the absence of third-party debt collection agencies (if all banks have to collect on their own), all banks use lenient debt collection practices in the first period.

(ii) If third-party debt collection agencies exist, then there exists a symmetric subgame perfect Nash equilibrium in pure strategies in which all banks delegate debt collection to third-party debt collection agencies and the agencies use harsh debt collection practices in both periods if the following restrictions are satisfied:

$$
\begin{aligned}
& f<\frac{\gamma(h-l)-[\beta \rho r(1-\gamma)-\beta \rho \gamma(1-h)] \frac{n-k}{n}}{\gamma h(1+\beta)} \\
& \frac{n-k}{n k}<\frac{h-l}{\beta \rho h} ; \\
& 1-\frac{1}{n}+\frac{1}{k N}>\frac{h-l}{\beta \rho h} .
\end{aligned}
$$

Proof. Part $(i)$. First consider the case in which there are no debt collection agencies and all banks have to collect on their own. We solve by backward induction. In the second period, all banks collect using harsh practices, regardless of the outcome of the first period. To see this clearly, compare the payoff to bank $i$ from using harsh practices in period two to this bank's payoff from using lenient practices in period two. By using harsh practices, bank $i$ obtains the following payoff in the second period:

$$
(1-\gamma) r Q_{i}^{2}\left(\lambda_{i}^{1} ; \lambda_{-i}^{1}\right)-\gamma(1-h) Q_{i}^{2}\left(\lambda_{i}^{1} ; \lambda_{-i}^{1}\right)
$$

By using lenient practices, bank $i$ obtains the following payoff in the second period:

$$
(1-\gamma) r Q_{i}^{2}\left(\lambda_{i}^{1} ; \lambda_{-i}^{1}\right)-\gamma(1-l) Q_{i}^{2}\left(\lambda_{i}^{1} ; \lambda_{-i}^{1}\right)
$$

The payoff in (A.2) is smaller than the payoff in (A.1) since $h>l$.

Since all banks will use harsh debt collection practices in the second period, the two-period payoff to bank $i$, if it and all other banks use harsh practices in the first period, is given by

$$
(1-\gamma) r \frac{1}{N} Q-\gamma(1-h) \frac{1}{N} Q+\beta(1-\gamma) r \frac{1}{N} Q-\beta \gamma(1-h) \frac{1}{N} Q
$$


If bank $i$ uses lenient practices in the first period while the other banks use harsh practices in the first period, bank $i$ 's two-period payoff is given by

$$
(1-\gamma) r \frac{1}{N} Q-\gamma(1-l) \frac{1}{N} Q+\beta(1-\gamma) r \frac{1+\rho}{N} Q-\beta \gamma(1-h) \frac{1+\rho}{N} Q
$$

The two-period payoff to the bank $i$, if it and all other banks use lenient practices in the first period, is given by

$$
(1-\gamma) r \frac{1}{N} Q-\gamma(1-l) \frac{1}{N} Q+\beta(1-\gamma) r \frac{1}{N} Q-\beta \gamma(1-h) \frac{1}{N} Q .
$$

If bank $i$ uses harsh practices in the first period while the other banks use lenient practices in the first period, bank $i$ 's two-period payoff is given by

$$
(1-\gamma) r \frac{1}{N} Q-\gamma(1-h) \frac{1}{N} Q+\beta(1-\gamma) r \frac{1-\rho}{N} Q-\beta \gamma(1-h) \frac{1-\rho}{N} Q
$$

Subtract (A.3) from (A.4) to obtain

$$
\gamma(l-h) \frac{1}{N} Q+\beta(1-\gamma) r \frac{\rho}{N} Q-\beta \gamma(1-h) \frac{\rho}{N} Q>0
$$

since $\beta \rho r(1-\gamma)-\beta \rho \gamma(1-h)>\gamma(h-l)$ by assumption.

Subtract (A.5) from (A.6) to obtain

$$
\gamma(h-l) \frac{1}{N} Q-\beta(1-\gamma) r \frac{\rho}{N} Q+\beta \gamma(1-h) \frac{\rho}{N} Q<0,
$$

since $\beta \rho r(1-\gamma)-\beta \rho \gamma(1-h)>\gamma(h-l)$ by assumption.

Hence, each bank's dominant strategy is to use lenient practices in the first period.

Part $(i i)$. Consider the following candidate equilibrium. In the first period, each bank delegates debt collection to $k$ debt collection agencies. If $\frac{k N}{n}$ banks delegate debt collection to agency $i$, then this agency uses harsh practices in both periods. If the number of banks that delegate debt collection to agency $i$ is smaller than $\frac{k N}{n}$, the agency uses lenient debt collection practices in the first period and harsh debt collection practices in the second period.

We solve by backward induction. First, notice that, as in Part $(i)$, the only Nash equilibrium for the subgame in the second period is to collect using harsh debt collection practices, whether a bank collects on its own or delegates debt collection 
to third-party agencies. Now consider the full game. Given the Nash equilibrium in the second period, the two-period payoff to bank $i$ in the conjectured equilibrium is given by

$$
(1-\gamma) r \frac{1}{N} Q-\gamma(1-h(1-f)) \frac{1}{N} Q+\beta(1-\gamma) r \frac{1}{N} Q-\beta \gamma(1-h(1-f)) \frac{1}{N} Q
$$

Now consider bank $i$ 's payoff if it decides to deviate by collecting on its own and using lenient practices in the first period. If bank $i$ decides to deviate while no other bank deviates, then there will be exactly $k$ debt collection agencies collecting on behalf of fewer than $\frac{k N}{n}$ banks (each of them will collect on behalf of $\frac{k N}{n}-1$ banks). As a result, they will use lenient debt collection practices. The remaining $n-k$ agencies, each collecting on behalf of $\frac{k N}{n}$ banks, will use harsh practices. Since market shares of the two types of agencies are different, care must be taken to determine the mass of borrowers who switch from their banks. The total number of bank-agency links is $k(N-1)$ since only $N-1$ banks delegate debt collection (to $k$ third-party agencies each). Of those, the number of links going to the agencies that used harsh debt collection practices equals $(n-k) \frac{k N}{n}$. In the first period, nondeviating banks provided, collectively, $\frac{N-1}{N} Q$ of credit to borrowers. The share of those borrowers who will switch their banks is given by $\rho \frac{(n-k) \frac{k N}{n}}{k(N-1)}$ (it equals the share of borrowers who faced harsh debt collection practices multiplied by their propensity to switch, $\rho$ ). After multiplying this share by the total amount of credit provided by the nondeviating banks, we obtain the total amount of credit demand associated with the borrowers who will switch in the second period: It equals $\rho \frac{(n-k)}{n} Q$. Of that demand, bank $i$ obtains $\frac{1}{N}$ share (since competing banks are equally likely to receive demand from switching borrowers), or $\rho \frac{(n-k)}{n N} Q$.

As a result, bank $i$ 's payoff in this case is given by

$$
\begin{aligned}
& (1-\gamma) r \frac{1}{N} Q-\gamma(1-l) \frac{1}{N} Q \\
& +\beta(1-\gamma) r\left(\frac{1}{N}+\rho \frac{n-k}{n N}\right) Q-\beta \gamma(1-h)\left(\frac{1}{N}+\rho \frac{n-k}{n N}\right) Q
\end{aligned}
$$

Subtract (A.9) from (A.10) to obtain

$$
\frac{1}{N} Q\left\{\gamma h f(1+\beta)+\gamma(l-h)+[\beta \rho r(1-\gamma)-\beta \rho \gamma(1-h)] \frac{n-k}{n}\right\}
$$


There is no incentive to deviate by using lenient practices if, and only if, this difference is less than zero. After some algebra, this can be rewritten as

$$
f<\frac{\gamma(h-l)-[\beta \rho r(1-\gamma)-\beta \rho \gamma(1-h)] \frac{n-k}{n}}{\gamma h(1+\beta)}
$$

Now consider bank $i$ 's payoff if it decides to deviate by collecting on its own and using harsh practices in the first period. In this case, it loses share $\rho$ of its own borrowers but gains $\rho \frac{(n-k)}{n N} Q$ borrowers that switch from their banks, as before. Bank $i$ 's payoff in this case is given by

$$
\begin{aligned}
& (1-\gamma) r \frac{1}{N} Q-\gamma(1-h) \frac{1}{N} Q \\
& +\beta(1-\gamma) r\left(\frac{1-\rho}{N}+\rho \frac{n-k}{n N}\right) Q-\beta \gamma(1-h)\left(\frac{1-\rho}{N}+\rho \frac{n-k}{n N}\right) Q
\end{aligned}
$$

It is immediate that the payoff in (A.13) is smaller than the payoff in (A.10) since $\beta \rho r(1-\gamma)-\beta \rho \gamma(1-h)>\gamma(h-l)$ by assumption. ${ }^{28}$ As a result, it is the restriction (A.12) that is binding. Hence, banks have no incentives to deviate by collecting on their own (by using either harsh or lenient debt collection practices) if, and only if, (A.12) holds.

Now consider third-party agencies. Similar to part $(i)$ above, using harsh debt collection practices in the second period is the dominant strategy for all agencies. In the conjectured equilibrium, each agency uses harsh debt collection practices in the first period if $\frac{k N}{n}$ banks delegate their debt collection to it; otherwise, it uses lenient debt collection practices in the first period. Therefore, an agency can deviate from the conjectured equilibrium in one of two ways: either by using lenient debt collection practices in the first period when $\frac{k N}{n}$ banks delegate their debt collection to it or by using harsh debt collection practices in the first period when fewer than $\frac{k N}{n}$ banks delegate their debt collection to it. We will now verify that neither of these deviations is profitable when all relevant restrictions are satisfied.

Since banks allocate the amount that needs to be collected evenly across the

\footnotetext{
${ }^{28}$ Deviating and using lenient practices yields a higher payoff than deviating and using harsh practices.
} 
agencies, the profit of an individual agency in the conjectured equilibrium is given by

$$
(1+\beta) h f \gamma \frac{1}{n} Q .
$$

Consider agency $j$ 's payoff if it deviates by using lenient practices in the first period after $\frac{k N}{n}$ banks delegate their debt collection to this agency. Consider any bank that hired this agency. This bank keeps the borrowers whose debts were collected by this agency. However, this bank also loses (with probability $\rho$ ) those borrowers whose debts were collected by other debt collection agencies this bank hired $(k-1$ of those agencies used harsh practices). Finally, this bank attracts (with probability $\rho$ ) new borrowers from other banks. The total number of bank-agency links is $k N$. Of those, the number of bank-agency links to agencies that used harsh practices is $(n-1) \frac{k N}{n}$. Therefore, each of the $\frac{k N}{n}$ banks that hired this agency will receive the following share of total demand in the second period:

$$
\frac{1}{N}-\rho \frac{k-1}{k} \frac{1}{N}+\rho \frac{1}{N} \frac{(n-1) \frac{k N}{n}}{k N} .
$$

After some algebra, (A.15) can be rewritten as

$$
\frac{1}{N}\left(1+\rho \frac{n-k}{n k}\right) .
$$

Each of the $\frac{k N}{n}$ banks that hired this agency delegated debt collection to $k$ agencies; therefore, this particular agency receives $\frac{1}{k}$ share of total collections for each of the $\frac{k N}{n}$ banks that hired it. As a result, this agency's payoff from using lenient practices in the first period is given by

$$
\text { lf } \gamma \frac{1}{n} Q+\beta h f \frac{1}{n} Q\left(1+\rho \frac{n-k}{n k}\right) .
$$

Subtract (A.14) from (A.17) to obtain

$$
\gamma \frac{1}{n} Q f\left(l-h+\beta h \rho \frac{n-k}{n k}\right) .
$$

There is no incentive for the agency to deviate by using lenient practices in the first period if, and only if, this difference is less than zero. After some algebra, this 
can be rewritten as

$$
\frac{n-k}{n k}<\frac{h-l}{\beta \rho h}
$$

Finally, we need to provide conditions such that the threat by third-party agencies to use lenient practices, if one of the banks deviates, is credible. Assume that one bank deviates and consider the payoff to one of the agencies that is hired by fewer than $\frac{k N}{n}$ banks. If this agency uses lenient debt collection practices in the first period (as in the conjectured equilibrium), its payoff is given by

$$
\operatorname{lf} \gamma Q \frac{N-1}{N} \frac{\frac{k N}{n}-1}{k(N-1)}+\beta h f \gamma Q \frac{N-1}{N}\left[\frac{\frac{k N}{n}-1}{k(N-1)}+\rho \frac{\frac{k N}{n}-1}{k N} \frac{(n-k) \frac{k N}{n}}{k(N-1)}\right]
$$

The intuition behind (A.20) is as follows. In the first period, this agency's share of the revenue collected by all agencies is equal to the number of this agency's bankagency links divided by the total number of bank-agency links (since by assumption banks allocate their collections evenly across the agencies they hire). Notice that the total revenue that banks assigned to all agencies equals $\gamma Q \frac{N-1}{N}$ since only $N-1$ banks used third-party agencies. In the second period, this agency keeps the share obtained in the first period (since it used lenient practices, the corresponding borrowers do not switch their banks), and it obtains a share of borrowers who switch banks equal to the number of this agency's bank-agency links divided by the total number of bank-agency links. Here, however, the total number of the links must be adjusted to include the equivalent number of links for the deviating bank: This bank does not lose its borrowers since it uses lenient practices, but it competes for the switching borrowers with the remaining $N-1$ banks. Notice also that the share of borrowers who switch banks equals the number of harsh bank-agency links divided by the total number of bank-agency links.

Analogously, if this agency deviates and uses harsh debt collection practices in the first period, its payoff will be given by

$$
\begin{aligned}
h f \gamma Q \frac{N-1}{N} \frac{\frac{k N}{n}-1}{k(N-1)}+ & \beta h f \gamma Q \frac{N-1}{N}\left[\frac{\frac{k N}{n}-1}{k(N-1)}(1-\rho)\right. \\
& \left.+\rho \frac{\frac{k N}{n}-1}{k N} \frac{(n-k) \frac{k N}{n}+\frac{k N}{n}-1}{k(N-1)}\right] .
\end{aligned}
$$


Subtract (A.21) from (A.20) to obtain

$$
f \gamma Q \frac{N-1}{N} \frac{\frac{k N}{n}-1}{k(N-1)}\left[l-h+\beta \rho h-\beta \rho h \frac{\frac{k N}{n}-1}{k N}\right] .
$$

This agency has no incentive to deviate from the equilibrium strategy by being harsh in the first period if, and only if, this difference is greater than zero. After some algebra, this can be rewritten as

$$
1-\frac{1}{n}+\frac{1}{k N}>\frac{h-l}{\beta \rho h}
$$

Proposition 2. For a given $G$, there exists a value of $n$ (the number of third-party debt collection agencies) that maximizes banks' profits.

Proof. First recall that banks' profits are higher in the delegated equilibrium, when it exists, than in the undelegated equilibrium (because of higher recovery rates). Now consider each bank's payoff in the delegation equilibrium:

$$
(1-\gamma) r \frac{1}{N} Q-\gamma(1-h(1-f)) \frac{1}{N} Q+\beta(1-\gamma) r \frac{1}{N} Q-\beta \gamma(1-h(1-f)) \frac{1}{N} Q
$$

It is easy to see that this payoff is a strictly increasing function of $h$. Since $h$ is a monotonically decreasing function of $G / n$, it follows that $h$ is a monotonically increasing function of $n$ for any given $G$. Therefore, the payoff in (A.24) is also an increasing function of $n$. Hence, the maximum value of $n$ that satisfies all restrictions of Proposition 1 is the value that maximizes banks' profits.

Proposition 3. Assume that $\beta \rho(\alpha-1)(1-h)>h-l$ and $\beta \rho(\alpha-1)(1-h) \frac{(\alpha+(\theta-\alpha) l)^{2}}{(\alpha+(\theta-\alpha) h)^{2}}>$ $h-l$. Then,

(i) In the absence of third-party debt collection agencies (if all banks have to collect on their own), all banks use lenient debt collection practices in the first period.

(ii) If third-party debt collection agencies exist, then there exists a symmetric subgame perfect Nash equilibrium in pure strategies in which all banks delegate debt 
collection to third-party debt collection agencies and the agencies use harsh debt collection practices in both periods if the following restrictions are satisfied:

$$
\begin{aligned}
& f<\frac{h-l-\beta \rho[(\alpha-1)(1-h)+\alpha h f] \frac{n-k}{k}}{h(1+\beta)} \\
& \frac{n-k}{n k}<\frac{h-l}{\beta \rho h} \\
& 1-\frac{1}{n}+\frac{1}{k N}>\frac{h-l}{\beta \rho h}
\end{aligned}
$$

Proof. Part $(i)$. First we will show that the equilibrium in which all banks use lenient debt collection practices in the first period exists. The proof is similar to that of Proposition 1, with the only difference that the amount of credit demand will be different across the two periods since banks use lenient debt collection practices in the first period and harsh debt collection practices in the second period. In the conjectured equilibrium, borrowers with default probabilities between 0 and $\frac{1}{\alpha+(\theta-\alpha) l}$ obtain credit in the first period, and borrowers with default probabilities between 0 and $\frac{1}{\alpha+(\theta-\alpha) h}$ obtain credit in the second period (since by the same logic as in Proposition 1, in the second period all banks collect using harsh practices).

The two-period payoff to bank $i$ if it and all other banks use lenient practices in the first period is given by

$$
\frac{1}{N}(\alpha-1)(1-l) \frac{1}{2(\alpha+(\theta-\alpha) l)^{2}}+\beta \frac{1}{N}(\alpha-1)(1-h) \frac{1}{2(\alpha+(\theta-\alpha) h)^{2}} .
$$

If bank $i$ deviates by using harsh practices in the first period while the other banks use lenient practices in the first period, bank $i$ 's two-period payoff is given by

$$
\frac{1}{N}(\alpha(1-l)-1+h) \frac{1}{2(\alpha+(\theta-\alpha) l)^{2}}+\beta \frac{1-\rho}{N}(\alpha-1)(1-h) \frac{1}{2(\alpha+(\theta-\alpha) h)^{2}}
$$

Subtract (A.25) from (A.26) to obtain:

$$
\frac{1}{2 N} \frac{h-l}{(\alpha+(\theta-\alpha) l)^{2}}-\beta \frac{\rho}{2 N} \frac{(\alpha-1)(1-h)}{(\alpha+(\theta-\alpha) h)^{2}}
$$


Thus, no bank has an incentive to deviate from the lenient equilibrium as long as

$$
h-l<\beta \rho(\alpha-1)(1-h) \frac{(\alpha+(\theta-\alpha) l)^{2}}{(\alpha+(\theta-\alpha) h)^{2}} .
$$

Now we will show that there is no equilibrium in which all banks collect on their own and use harsh debt collection practices when $\beta \rho(\alpha-1)(1-h)>h-l$. We prove by contradiction. Assume that such an equilibrium exists. In this case, the interest rate that the banks charge borrowers with default probability $\gamma$ will be given by $\alpha \frac{\gamma(1-h)}{1-\gamma}$ in each period. The mass of borrowers who demand credit will be the same in both periods (since the harshness of debt collection practices they face and the interest rate they are charged is the same in both periods). Since total credit demand and interest rates do not vary across periods, we can simplify the problem by considering the equilibrium outcome for each level of default probability $(\gamma)$. For every value of $\gamma$, the interest rate is known and is constant in both periods, and the problem is now equivalent to that in Proposition 1. There, the equilibrium in which banks use harsh debt collection practices in the first period does not exist as long as $\beta \rho r(1-\gamma)-\beta \rho \gamma(1-h)>\gamma(h-l)$. By substituting $r=\alpha \frac{\gamma(1-h)}{1-\gamma}$ into this condition, we obtain $\beta \rho(\alpha-1)(1-h)>h-l$. Hence, the equilibrium in which banks use harsh debt collection practices in the first period does not exist.

Part (ii). In the delegated equilibrium, if it exists, borrowers with default probabilities between 0 and $\frac{1}{\alpha+(\theta-\alpha) h}$ will obtain credit in both periods. Conditional on $\gamma$, the interest rate is known in both periods and is given by $r=\alpha \frac{\gamma(1-h(1-f))}{1-\gamma}$. Hence, we can again simplify the problem by considering the equilibrium outcome for each level of default probability $(\gamma)$. The problem is now equivalent to that in part (ii) of Proposition 1. There, the delegated equilibrium exists as long as the following restrictions are satisfied:

$$
\begin{aligned}
& f<\frac{\gamma(h-l)-[\beta \rho r(1-\gamma)-\beta \rho \gamma(1-h)] \frac{n-k}{k}}{\gamma h(1+\beta)} \\
& \frac{n-k}{n k}<\frac{h-l}{\beta \rho h} \\
& 1-\frac{1}{n}+\frac{1}{k N}>\frac{h-l}{\beta \rho h} .
\end{aligned}
$$

All that remains is to replace $r$ with the endogenously derived interest rate, $r=$ 
$\alpha \frac{\gamma(1-h(1-f))}{1-\gamma}$, in the first restriction above to obtain:

$$
\begin{aligned}
& f<\frac{h-l-\beta \rho[(\alpha-1)(1-h)+\alpha h f] \frac{n-k}{k}}{h(1+\beta)} \\
& \frac{n-k}{n k}<\frac{h-l}{\beta \rho h} \\
& 1-\frac{1}{n}+\frac{1}{k N}>\frac{h-l}{\beta \rho h} .
\end{aligned}
$$

As long as all restrictions in (A.29) are satisfied, no bank will have an incentive to deviate from the delegated equilibrium, regardless of borrowers' default probability.

Proposition 4. Borrower welfare in the delegated equilibrium can be higher or lower than borrower welfare in the undelegated equilibrium, depending on parameter values.

Proof. It is easy to verify that $W_{d}>W_{u}$ for the following set of parameter values: $f=0.2, \beta=0.8, h=0.5, l=0.2, \alpha=2, \theta=0.3$. These parameter values satisfy all the restrictions of Proposition 3.

It is also easy to verify that $W_{d}<W_{u}$ for the following set of parameter values: $f=0.2, \beta=0.8, h=0.5, l=0.2, \alpha=2, \theta=0.7$. These parameter values satisfy all the restrictions of Proposition 3.

Thus, total welfare in the delegated equilibrium can be higher or lower than in the lenient equilibrium, depending on parameter values. 